\title{
Floating rafts as breeding habitats for the Common tern, Sterna hirundo. Colonization patterns, abundance and reproductive success in Venice Lagoon
}

\author{
Francesca Coccon ${ }^{1 *}$, Stefano Borella ${ }^{2}$, Nicola Simeoni ${ }^{1}$, Stefano Malavasi ${ }^{1}$
}

\begin{abstract}
The Venice lagoon hosts the 15\% of the entire Italian breeding population of Common terns, Sterna hirundo, highlighting the great value of the area for this species. However, in the last 25 years, a substantial decline of Common terns has been detected in the Lagoon, which culminated in 2008. The main causes of this negative trend were the loss of salt marsh habitats, where terns typically breed in the Venice lagoon. This was due to the increase in the mean sea level and the greater frequency of high tides during the reproductive period with consequent flooding of their breeding sites; competition with yellowlegged gulls (Larus michahellis), predation and human disturbance. As a preliminary experimental approach to counter the depletion of the species and favour its recovery, we performed a habitat loss compensation project by setting up four floating rafts $(3 \times 2 \mathrm{~m})$, covered by two different types of substrate (sandy and vegetal substrate). This was to function as an artificial nesting site safe from flooding, positioned in a protected internal wetland area of the Venice lagoon, Valle Averto (Sourthern Lagoon). We studied the colonization patterns of the rafts and the reproductive success of Common tern breeding pairs during the 2014 and 2015 breeding seasons. We also investigated those environmental and structural variables that could favour the use of the rafts and the nesting success of the species. In both years, the rafts were successfully colonized and used by terns for nesting. Our results also indicated higher temperature, lower rainfall and greater distance from the shore as the main habitat factors favouring the occurrence and the reproductive success of the breeding pairs, while a windrow of dead plants was indicated as the preferred substrate for covering rafts in order to make them more attractive. The results provided some suggestions for successful restoration plans to be developed in similar lagoon areas.
\end{abstract}

Key words: Common tern, floating rafts, habitat loss compensation, colonization patterns, breeding success, Venice lagoon.

Riassunto - Zattere galleggianti come habitat di riproduzione per la Sterna comune, Sterna hirundo. Processi di colonizzazione, abbondanza e successo riproduttivo nella Laguna di Venezia.

\footnotetext{
Dipartimento di Scienze Ambientali, Informatica e Statistica, Università Ca' Foscari di Venezia, Campus scientifico, Via Torino 155, 30172 Venezia Mestre (VE), Italia.

${ }^{2}$ WWF Oasi Società Unipersonale a r.1., Via Po 25/c, 00198 Roma, Italia.

* Corresponding author: francesca.coccon@hotmail.it

(C) Francesca Coccon, Stefano Borella, Nicola Simeoni, Stefano Malavasi
}

Received: 11 July 2017

Accepted for publication: 10 September 2017
La laguna di Venezia ospita il 15\% del contingente nidificante italiano di sterne comuni, Sterna hirundo, evidenziando il grande valore dell'area per questa specie. Tuttavia, negli ultimi 25 anni, è stato rilevato un notevole declino della popolazione nidificante in Laguna, che è culminato nel 2008. Le cause principali di questo trend negativo sono state la perdita di barene, dove le sterne tipicamente si riproducono nella laguna di Venezia, dovuta all'aumento del livello medio del mare e alla maggiore frequenza delle alte maree durante il periodo riproduttivo con conseguente sommersione dei siti di riproduzione; la competizione con il gabbiano reale (Larus michahellis); la pressione predatoria da parte di altre specie ed il disturbo umano. Per contrastare il decremento locale della specie e favorirne il recupero, abbiamo messo in atto un progetto sperimentale di compensazione della perdita dell'habitat riproduttivo, installando quattro zattere galleggianti $(3 \times 2 \mathrm{~m})$, coperte da due diversi tipi di substrato (substrato sabbioso e vegetale). Queste zattere dovevano ricreare dei siti di nidificazione artificiale per la specie, esenti da inondazioni e posizionate in una zona umida protetta della laguna di Venezia: Valle Averto (nel bacino meridionale della Laguna). Nel corso dello studio, abbiamo seguito i processi di colonizzazione delle zattere e il successo riproduttivo delle coppie nidificanti durante le stagioni 2014 e 2015. Abbiamo anche analizzato le variabili ambientali e strutturali che potevano favorire l'uso delle zattere e il successo di nidificazione della specie. In entrambi gli anni, le zattere sono state colonizzate con successo e utilizzate dalle sterne per la nidificazione. I nostri risultati hanno inoltre indicato temperature più elevate, un minor tasso di precipitazione e una maggior distanza dalla riva come i principali fattori che favoriscono la presenza e il successo riproduttivo delle coppie riproduttive, mentre il substrato vegetale si è dimostrato il migliore per ricoprire le zattere al fine di renderle più attrattive per la specie. I nostri risultati forniscono alcuni suggerimenti per il successo dei piani di habitat restoration da attuare in aree lagunari simili.

Parole chiave: Sterna comune, zattere galleggianti, ripristino dell'habitat, processi di colonizzazione, successo riproduttivo. Laguna di Venezia.

\section{INTRODUCTION}

Habitat loss, fragmentation and degradation are the most important causes of species decline and extinction (Tilman et al., 1994; Fahrig, 1997; Huxel \& Hastings, 1999). Such aspects are determined by the heavy impact of humans on the natural environment and climate (Mantyka-pringle et al., 2012; Goudie, 2013). All these anthropogenic activities alter the habitat available for most species, usually leading to a reduction in biodiversity (Dobson et al., 1997) and populations decline (Andren, 1994; Fahrig, 1997; Bender et al., 1998). To counter the depletion of biological and ecological biodiversity, in recent years a new discipline is emerging, the restoration ecology. Clarke and colleagues (2010) defined the ecological 
restoration as the assisted recovery of degraded ecological systems. A primary motivation for undertaking restoration is often to increase the amount of habitat present in a given area (Miller \& Hobbs, 2007). Habitat restoration focuses on providing suitable environments and resources for target species or groups of species that are currently in decline due to past habitat loss or degradation (Clarke et al., 2010). Croxall and colleagues (2012) showed that overall, seabirds are more threatened than all other groups of birds with comparable numbers of species, due to a number of different factors, including climate change and the impact of sea level rise (Grémillet \& Boulinier, 2009; Croxall et al., 2012).

Climate threats, in association with human disturbance and predation at nesting sites are currently affecting the Common tern, Sterna hirundo, especially during the breeding season. The Common tern is a colonial seabird with a wide breeding range that includes most of Europe, Asia and North America, except the extreme north and south. In Europe, recent estimates indicate a large population of 316.000-605.000 pairs and the European population trend for the species appears to be stable and, in some cases, in increase (BirdLife International, 2016). Given its extremely large range and the large population size, the species is evaluated as Least Concern in the IUCN Red List of Threatened Species (BirdLife International, 2016). Despite this stable trend at the European level, on a National scale the species has recorded cases of localized decline (Peronace et al., 2012). The Italian population was estimated between 4.000 and 5.000 pairs (Brichetti \& Fracasso, 2006), of which more than $15 \%$ in the Venice lagoon (Bon et al., 2014). However, since 1989 the Common Tern breeding in the Venice lagoon showed a negative trend (Scarton \& Valle, 2016), with a minimum of 109 pairs in 2008 (Scarton, 2010) followed by a moderate recovery since 2012 (Scarton \& Valle, 2016).

The causes of this negative trend of the species are due to several factors: a) the loss of salt marsh habitats, where Common terns typically breed in Venice lagoon (Scarton, 2010) as a result of the effects of anthropogenic-induced erosion, subsidence and relative sea level rise that occurred in Venice lagoon in the last decades (Cavraro et al., 2017); b) the greater frequency of high tides in the reproductive period, from May to June, leading to a complete flooding of the breeding sites of Common terns and a consequent loss of the nests (Scarton, 2010); c) predation on eggs, chicks, or adults by birds of prey such as Marsh harrier, Circus aeruginosus, Montagu's harrier, Circus pygargus, and Peregrine falcon, Falco peregrinus, mammals, in particular rats, Rattus norvegicus, the latter primarily affecting at sites close to the mainland (Valle \& Scarton, 1999) and Yellow-legged gulls, Larus michahellis, whose predation on the terns' nests has been widely documented (Becker, 1995; Magella \& Brousseau, 2001; O'Connell \& Beck, 2003; Scarton, 2008). This species also competes with Common terns for suitable nesting sites, by colonizing them 1-2 months earlier (Fasola \& Canova, 1991). Finally, the negative effects of human disturbance on the breeding success of nesting colonial waterbirds are largely known (Burger, 1981; 1998; Carney \& Sydeman, 1999; Gill, 2007; Scarton, 2010).
To counter the above mentioned threats and favour the recovery of the species, the use of floating rafts at selected sites was proposed as a successful tool for a) providing alternative breeding habitats for Common terns that are not susceptible to erosion, not occupied by gulls and isolated from ground predators and human disturbances and b) increasing the breeding population and the reproductive success of the species (Dunlop et al., 1991; Burgess \& Hirons, 1992; Lampman et al., 1996; Rocco \& Utmar, 2011).

In this study, we installed four floating rafts in the WWF naturalistic oasis of Valle Averto (Southern Venice Lagoon) as a pilot habitat loss compensation project, in an effort to increase the reproductive success of the Common tern in the study area.

Our aims were: 1) to investigate the use and colonization patterns of floating rafts by the Common terns over two consecutive breeding seasons (2014 and 2015); 2) to study those factors, environmental and structural, influencing the colonization of the rafts and the breeding success of the pairs in the studied period and 3) to investigate the success of using the floating rafts as artificial breeding sites for Common terns, safe from flooding, inexpensive and easy to be located within areas subject to tidal variations.

\section{MATERIALS AND METHODS}

\section{Study area and data collection}

The study was conducted in Valle Averto, located in the southern basin of the Venice lagoon, in the municipality of Campagna Lupia, Province of Venice, Italy $\left(45^{\circ} 21^{\prime} \mathrm{N}, 12^{\circ} 09^{\prime} \mathrm{E}\right)$ (Fig. 1). The area is about 500 ha. Of these, about 83 ha are owned by the World Wild Fund for Nature, WWF and include emerged lands, freshwater wetlands, two brackish lakes and saltmarshes; 290 ha are owned by the Averto Marine Company AMA s.r.l. which is dedicated to aquaculture and that is mainly represented by the Big Lake of the Averto, a brackish basin, neighbouring to the two lakes of the naturalistic oasis WWF and deeper than these. The remaining part is owned by three families native of the area and it is characterized by permanent pastures and agricultural fields. The study area has a particular importance from an environmental and conservationist point of view, being included in the list of wetlands of international importance, according to the Ramsar Convention. It also lies within the Site of Community Importance of the middle and lower Venice lagoon (SIC IT3250030) and the Special Protection Area extended to the entire lagoon basin (ZPS IT3250046).

Based on previous studies (Dunlop et al., 1991; Burgess \& Hirons, 1992; Lampman et al., 1996; Rocco \& Utmar, 2011), we built four rafts that could be used as nesting sites by Common terns. The rafts have a dimension of $3 \times 2 \mathrm{~m}$, with the perimeter base made of PVC hollow tubes to allow the structure to float and painted grey to make it less invasive. The bottom of the rafts was made with wooden rods, on the top of which we placed geotextile. Rafts were perimeter delimited by a $100 \times 65 \mathrm{~cm}$ mesh net to prevent yellow-legged gulls getting in and preying on the eggs and chicks of Common terns. We also placed 

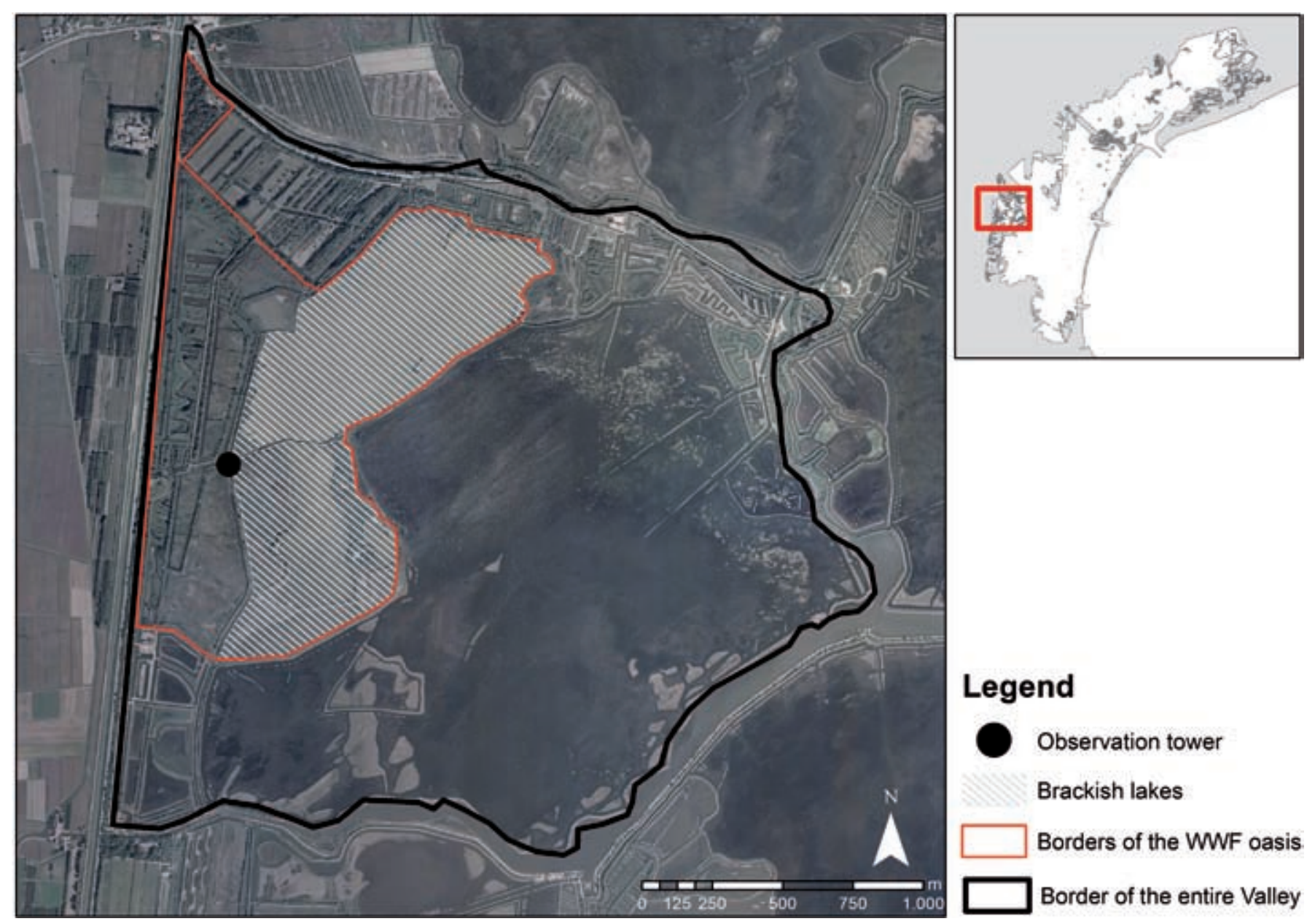

Fig. 1 - Territorial framework of Valle Averto and delimitation of the naturalistic oasis WWF. The two lakes are marked with white oblique stripes.

a second net, $15 \mathrm{~cm}$ high, at the base of the rafts to prevent chicks from accidentally falling into the water. Rafts were covered with two habitats of election for nesting terns. Thus we scattered sand and shells over two of them and dead beached seaweed (hereafter windrow) on the remaining two (Burger \& Lesser, 1978; Scarton, 2010). Finally, we placed a fake decoy of an hatching tern within each raft, in order to attract individuals (Fig. 2). Rafts were then located in the two lakes of the WWF oasis at an increasing distance from the shore, starting from $60 \mathrm{~m}$, to limit the possibility of being reached by terrestrial predators and the human disturbance created by the visitors of the oasis. To prevent drifting, the rafts were anchored on hunting barrels or poles already present in the study area.

The monitoring activity was conducted between April and July both in 2014 and in 2015. Throughout the study, data were collected once a week on an hourly basis from 8:00 to $11: 00$ and from 15:00 to $16: 00$ and observations were performed from a fixed elevated vantage point (i.e. birdwatching tower of the oasis) from which the study area was clearly visible. To assess colonization patterns of the rafts by the Common terns, the following variables were quantified: number of individuals in low flight or roosting in a radius of $10-15 \mathrm{~m}$ from the raft (hereafter referred to as "around"); number of individuals coming and going from the rafts without staying in them for more than few seconds ("in/around"); number of individuals in low flight over the raft or roosting inside ("in"). Therefore, the dataset used for the analysis is organized by date and time of sampling, the raft with relative features (i.e. distance from the shore and type of substrate) and the above mentioned variables (i.e. around, in/around and in), reaching a sample size of $\mathrm{N}=1632$ records. We also recorded the abundance of breeding pairs, defined as pairs laying a clutch, chicks born and chicks fledged observed in the rafts during the surveys, to document the breeding success of Common terns in the two years of study. However, such observations (e.g. the exchange between the adult pair in the hatching of eggs, behaviour that was observed with a 20-30 minutes interval, or the observation of the chicks in the nest or the first flights of juveniles) were recorded at the time in which they were observed for the first time in the course of sampling and were not repeated at hourly intervals. Therefore, in this case data are organized by date of sampling and raft to which the observations refer, reaching a sample size of 112 records.

For this study we also used data on weather conditions (i.e. air pressure, ATM (mbar), solar radiation $(\mathrm{W} / \mathrm{m} 2)$, temperature $\left({ }^{\circ} \mathrm{C}\right)$, wind speed $(\mathrm{m} / \mathrm{s})$, rainfall $\left.(\mathrm{mm})\right)$. Such data were recorded, on an hourly basis, at the meteorolo- 


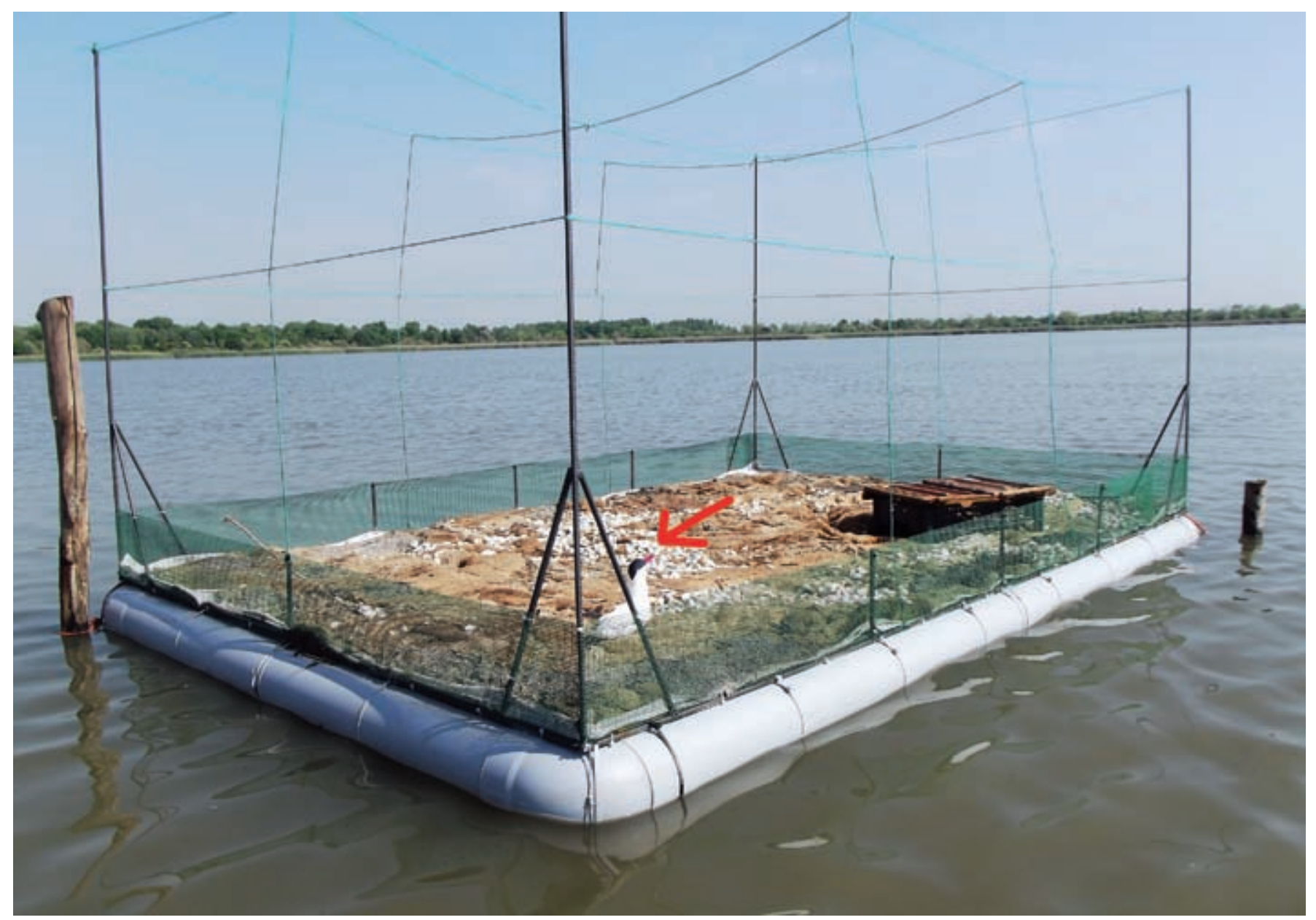

Fig. 2 - Floating raft set up in the study to favour the nesting of Common terns in the WWF oasis of Valle Averto. The arrow points the fake decoy of an hatching tern, placed on the rafts to attract individuals.

gical station of Teolo $(45.361 \mathrm{~N}, 11.673 \mathrm{E})$ and were provided by ARPAV, the Regional Agency for Environmental Protection and Prevention of the Veneto region.

\section{DATA ANALYSIS}

In order to assess whether there was a difference in the use of the rafts by Common terns between the two years of study, data were analysed with matched-pairs tests. For this purpose we focused on a restricted sample of $\mathrm{N}=1088$ observations by considering the only around and in variables, the most relevant behaviours recorded during surveys, while the around/in one was omitted from the analysis. We calculated the mean value for each variable (around and in) across the breeding season 2014 and 2015 and compared them using the non-parametric Wilcoxon Signed Ranks Test, since the selected variables were not normally distributed. We also examined whether there was a difference in the reproductive success of terns through a qualitative comparison in the number of breeding pairs that colonized the rafts, the number of chicks born and chicks fledged in the two seasons.

We then focused on those factors that had changed between the two years of study, which may have affected the colonization of rafts and the reproductive success of Common terns. We first considered the distance of rafts from the shore. As mentioned above, in both the years of study rafts were placed at increasing distances from the shore, therefore there were both intra and inter-annual differences among them. We evaluated whether individuals were distributed significantly differently in the rafts, depending on their distance from the shore, by applying the non-parametric Friedman test on the average number of individuals calculated per each distance of rafts and month of sampling $(n=4$, per year of study). The statistical test was performed for the two years of study, both separately and together. Further, we compared the selected weather conditions recorded in the two studied breeding seasons (from April to July 2014 and 2015), using the Wilcoxon Signed Ranks Test.

Finally, we investigated the effects of the type of substrate with which the rafts were covered, the distance of rafts from the shore and the selected weather variables, on the number of individuals of Common terns that used the floating rafts and on the abundance of breeding pairs, chicks born and chicks fledged observed in the rafts during surveys. In the first case we used the hourly dataset considering all the available observations $(\mathrm{N}=1632)$; in the second one we used the daily dataset $(\mathrm{N}=112)$, by 
calculating the average value of each weather variable per date of sampling with the exception of the rainfall for which we calculated the total amount per day.

Explorative analyses showed that the residuals of the data were not normally distributed. Therefore, we formulated four Generalized Linear Models (GLMs) with Poisson distribution and a log link function to optimise the models. To test for the reliability of the estimates from the GLM models we performed a robustness test by fitting a robust regression, particularly indicated when heteroscedasticity and large variance occur, as in the case of weather variables. All data were analysed using R version 3.3.1 (R Core Team, 2016) (http://www.rproject.org/) and significance was set at $P<0.05$ for all the performed analyses.

\section{RESULTS}

We found a significant difference in the number of Common terns "around" and "in" the rafts between the two years of study (Wilcoxon Signed Ranks test, around: $\mathrm{V}=911, P=1.138 \mathrm{e}-10$; in: $\mathrm{V}=3505.5, P=6.152 \mathrm{e}-06)$, with an evident increase of both the variables in 2015 (Fig. 3).

Results also indicated an increased tendency of the Common tern breeding success in 2015 compared to 2014 (Table 1). In fact, in the first year of the study two breeding pairs were recorded, which had colonized two of the four available rafts. Differently, in 2015 we registered a breeding pair per each raft. Again, in 2014 the two pairs have laid three eggs each, from which six chicks were born (three chicks per pair) after about three weeks. Of these chicks, half died before fledging, presumably between the second and third week of their life. On the contrary in 2015 , ten chicks were born (three for rafts 1 and 4 and two for the remaining ones), eight of which fledged (Table 1). Therefore, an increase of $30 \%$ of the survival rate of nestlings (chicks fledged/chicks born) was recorded in 2015 .

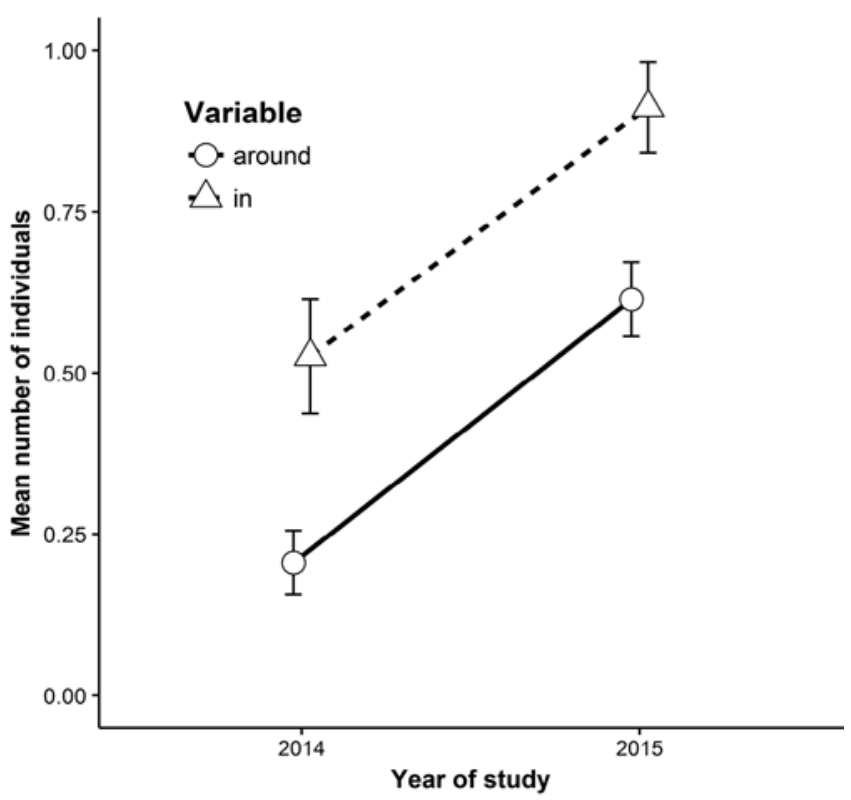

Fig. 3 - Mean ( \pm s.e.) number of individuals for the two studied variables of colonization pattern of the rafts (around and in), across the two years of study.
Tab. 1 - Number of breeding pairs, chicks born and chicks fledged recorded per raft across the two years of study.

\begin{tabular}{|l|c|c|c|c|}
\hline Year of study & Raft & $\begin{array}{c}\text { Breeding } \\
\text { pairs }\end{array}$ & $\begin{array}{c}\text { Chicks } \\
\text { born }\end{array}$ & $\begin{array}{c}\text { Chicks } \\
\text { fledged }\end{array}$ \\
\hline \multirow{3}{*}{2014} & 1 & 0 & 0 & 0 \\
\cline { 2 - 5 } & 2 & 1 & 3 & 2 \\
\cline { 2 - 5 } & 3 & 0 & 0 & 0 \\
\cline { 2 - 5 } & 4 & 1 & 3 & 1 \\
\hline Total amount & & $\mathbf{2}$ & $\mathbf{6}$ & $\mathbf{3}$ \\
\hline \multirow{3}{*}{2015} & 1 & 1 & 3 & 2 \\
\cline { 2 - 5 } & 2 & 1 & 2 & 2 \\
\cline { 2 - 5 } & 3 & 1 & 2 & 2 \\
\cline { 2 - 5 } & 4 & 1 & 3 & 2 \\
\hline Total amount & & $\mathbf{4}$ & $\mathbf{1 0}$ & $\mathbf{8}$ \\
\hline
\end{tabular}

For both years of study, we found no statistically significant difference in the number of Common terns recorded in the rafts located at different distances from the shore (Friedman test, 2014: $\chi_{3}^{2}=6.243, P=0.100 ; 2015: \chi_{3}^{2}=$ 5.700, $P=0.127)$. However, differences were significant once the data from the two years were pooled together $\left(\chi^{2}=16.838, P=0.018\right)$, with a higher occurrence of individuals in the rafts with greater distances from the shore (Fig. 4). We point out that the statistical test has been applied on the average number of individuals calculated for each distance of the rafts and month of sampling, per year of study ( $\mathrm{N}=32$ observations), while the graph in Figure 4 represents the average number of individuals per year of study and distance of the rafts from the shore $(\mathrm{N}=8$ observations). The graph also highlights that distances of the rafts were mostly higher in 2015, compared to 2014 (Fig. 4). The increased distance in 2015 may have had a positive effect on the use of the rafts by Common terns.

Amongst the weather variables considered for the analysis, only air pressure, solar radiation and average temperature have significantly changed between the two years of study (Wilcoxon Signed Ranks test, air pressure ATM: $\mathrm{V}=725700, P<2.2 \mathrm{e}-16$; solar radiation: $\mathrm{V}=$ 508280, $P=0.024$; av. temperature: $\mathrm{V}=846780, P<2.2 \mathrm{e}-$ 16), with a clear increase in 2015 compared to 2014, especially in June and July (Fig. 5). Differences between the two years were not significant for the other selected weather variables (in all cases $P>0.05$ ). However, in April and July 2015, corresponding respectively to the formation of couples and colonization of nesting sites and the fledging phase of chicks, almost no rainfall had been recorded, contrary to the previous breeding season characterized by a rather intense rainfall for the entire period of study (Fig. 6 ). The positive weather conditions, in association with the increased temperature and low rainfall, recorded in the breeding season 2015 may have had a positive effect on the reproductive success of Common terns.

The GLM analysis revealed a significant effect of all the considered variables, with the exception of the wind speed, on the number of individuals that use the floating rafts (Ta- 


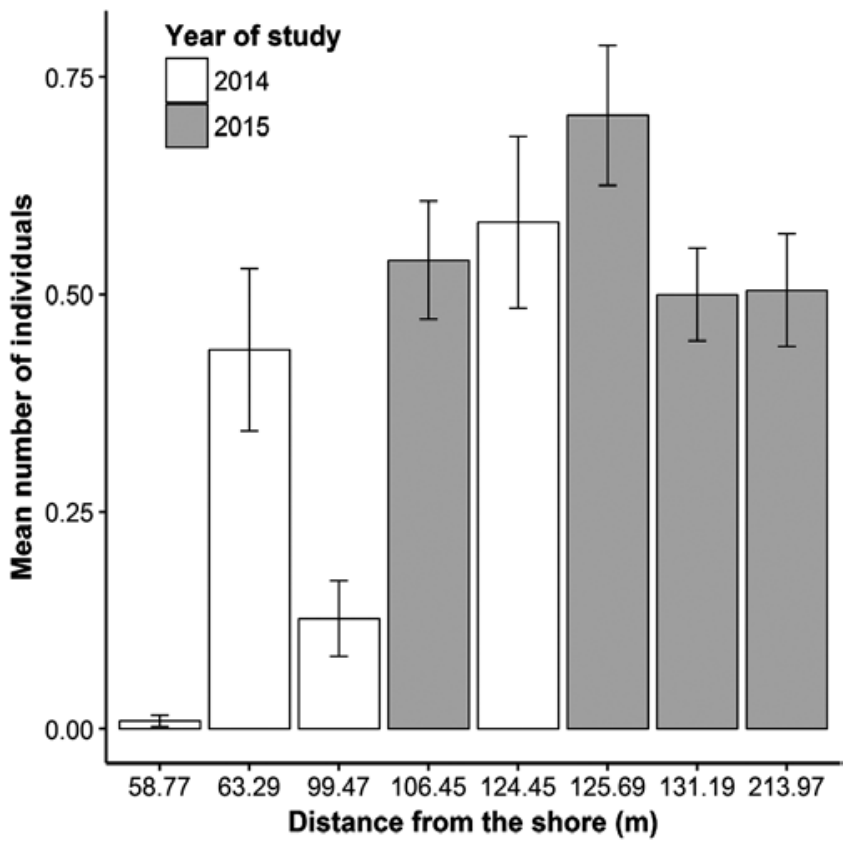

Fig. 4 - Mean $( \pm$ sem) number of individuals registered in the rafts located at different distances from the shore, in the two years of study.

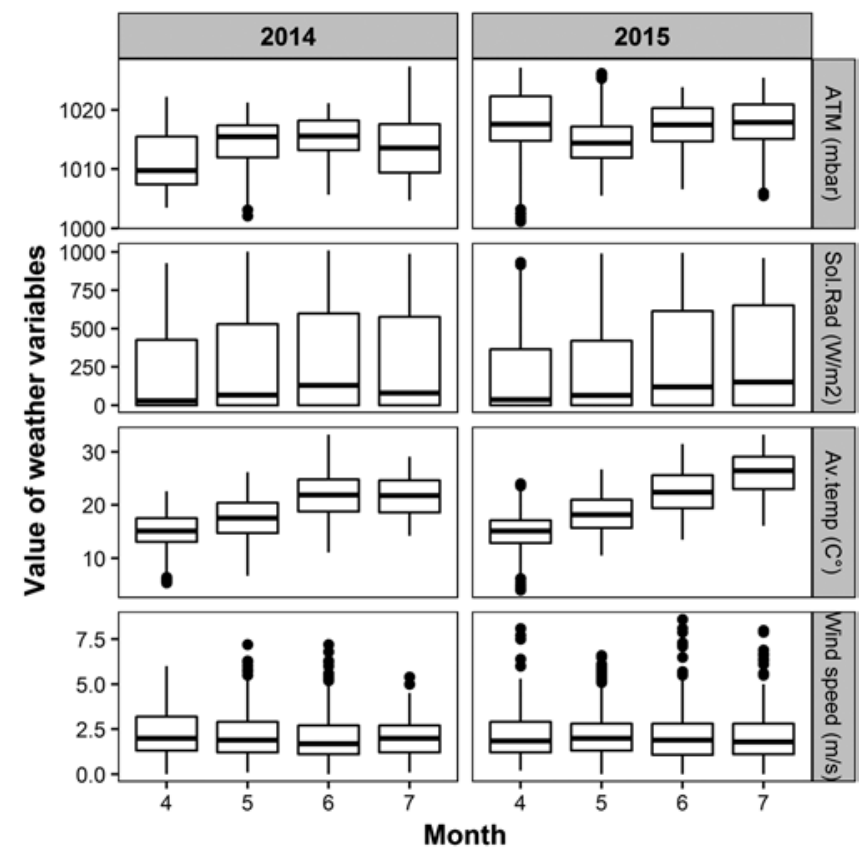

Fig. 5 - Box plots of the selected weather variables, from April to July, in the two years of study.

ble 2, first column). In particular, the greater the distance of the rafts from the shore, the average temperature and the air pressure, the higher the abundance of Common terns. Also, an increase in rainfall lessened the number of individuals. Specifically, there was a reduction of 1.2 individuals per $\mathrm{mm}$ of rainfall. There was also a trend in that rafts covered with windrow showed to host a significant higher number of individuals than the rafts covered by sand and shells. The estimated coefficients of the robust regression, performed as robustness check of the calibrated GLM model, are shown in the second column of Table 2. The magnitude of

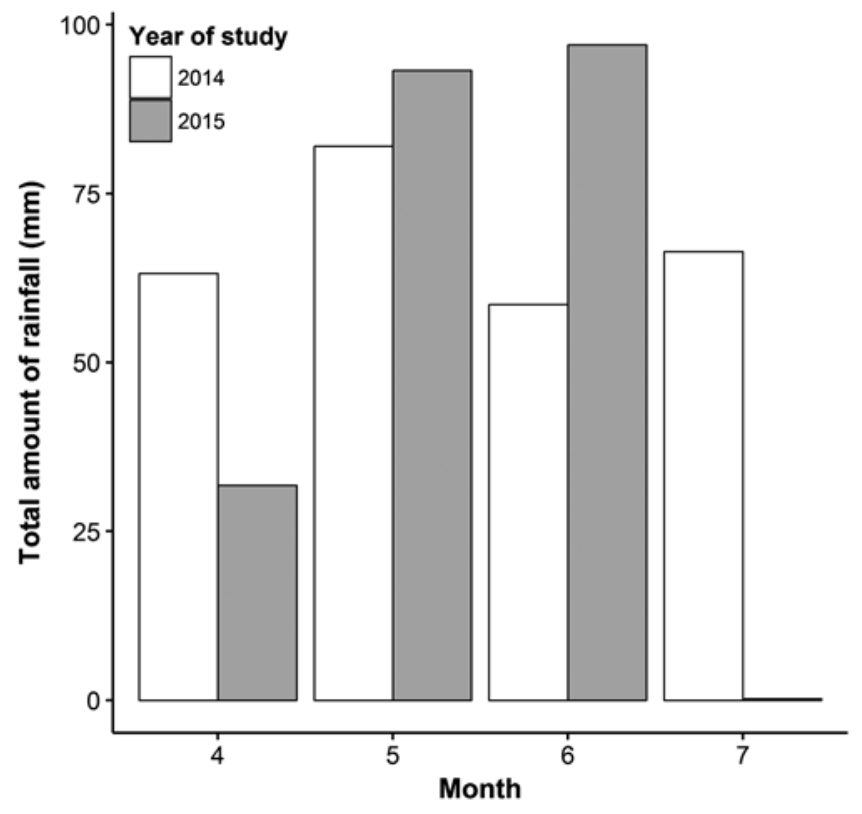

Fig. 6 - Bar plot showing the total amount of rainfall recorded, by month, in the two studied years.

coefficients does not change between the two models, as well as the significance level of the investigated explanatory variables, with the exception of the wind speed that showed significant effect in the robust regression.

The calibrated GLMs to investigate the effects of the selected explanatory variables on the abundance of breeding pairs, chicks born and chicks fledged recorded within the floating rafts during surveys are shown in Table 3 (columns 1-3). The results highlighted that higher average temperatures significantly and positively affected the three dependent variables. Wind speed had significant effect solely on the chicks born, while the increased distance of the rafts from the shore and solar radiation significantly increased the number of chicks fledged. Further, it was pointed out that an increase in air pressure significantly lowered the number of chicks born, while on the other side it significantly raised the number of chicks fledged. The vegetal substrate had also significant positive effect on the chicks fledged compared to the sandy one (Table 3, 1-3 columns). The estimates of the GLMs are compared with those from robust regression analysis, which are displayed in columns 4-6 of Table 3. Estimated coefficients and significance effect of the investigated explanatory variables closely resemble those of the GLM for the chicks born, indicating the robustness of the results. Coefficients with similar magnitude between the two models were found in the case of breeding pairs, even if robust regression pointed out two additional significant factors (i.e. distance from the shore and rainfall). On the contrary, the model relative to chicks fledged appeared to not be robust, with no significant effect of the explanatory variables, apart from the average temperature that showed a significant positive effect. This lack of significance may be explained by the overabundance of zero in the dependent variable. Tables 2 and 3 have been created using the stargazer library from the 'stargazer' R package (Hlavac, 2015). 
Table 2 - Coefficient estimates with standard errors listed in parentheses of the fitted GLM and robust regression models. One, two and three stars correspond to the estimated coefficient being statistically significant at the 10, 5 and 1 percent significance levels, respectively.

\begin{tabular}{|l|c|c|}
\hline \multirow{2}{*}{} & \multicolumn{2}{|c|}{$\begin{array}{c}\text { Dependent variable } \\
\text { N. individuals }\end{array}$} \\
\cline { 2 - 3 } & $(1)$ & $(2)$ \\
\hline Distance from the shore(m) & $0.006^{* * *}$ & $0.00000^{* * *}$ \\
\hline & $(0.001)$ & $(0.00000)$ \\
\hline Substrate (windrow) & $0.362^{* * *}$ & $0.0001^{* * *}$ \\
\hline & $(0.090)$ & $(0.00003)$ \\
\hline Rainfall $(\mathrm{mm})$ & $-1.197^{* *}$ & $-0.00002^{* *}$ \\
\hline Sol. Rad.(W/m2) & $(0.581)$ & $(0.00001)$ \\
\hline & $-0.001^{* * *}$ & $-0.00000^{* * *}$ \\
\hline Av. temp(C) & $(0.0002)$ & $(0.00000)$ \\
\hline & $0.056^{* * *}$ & $0.00003^{* * *}$ \\
\hline Wind speed(m/s) & $(0.011)$ & $(0.00000)$ \\
\hline & 0.038 & $0.00004^{* * *}$ \\
\hline ATM(mbar) & $(0.029)$ & $(0.00001)$ \\
\hline & $0.041^{* * *}$ & $0.00001^{* * *}$ \\
\hline Constant- & $(0.009)$ & $(0.00000)$ \\
\hline & $43.669^{* * *}$ & $-0.015^{* * *}$ \\
\hline Observations & $(9.320)$ & $(0.004)$ \\
\hline Log Likelihood & 1,632 & 1,632 \\
\hline Akaike Inf. Crit. & $-1,534.717$ & \\
\hline Residual Std. Error & $3,085.434$ & $0.001(\mathrm{df}=1624)$ \\
\hline Note: & & $* \mathrm{p}<0.1 ; * * \mathrm{p}<0.05 ; * * * \mathrm{p}<0.01$ \\
\hline
\end{tabular}

Table 3 - Coefficient estimates with standard errors listed in parentheses of the fitted GLMs and robust regression models. One, two and three stars correspond to the estimated coefficient being statistically significant at the 10,5 and 1 percent significance levels, respectively.

\begin{tabular}{|c|c|c|c|c|c|c|}
\hline & \multicolumn{6}{|c|}{ Dependent variable } \\
\hline & Breed. pairs & Chicks born & Chicks fledged & Breed. Pairs & Chicks born & Chicks fledged \\
\hline & $(1)$ & $(2)$ & (3) & (4) & $(5)$ & $(6)$ \\
\hline Distance from the shore $(\mathrm{m})$ & 0.005 & 0.001 & $0.020 * * *$ & $0.003 * * *$ & 0.00002 & 0.00000 \\
\hline \multirow[t]{2}{*}{ Substrate (windrow) } & 0.220 & 0.060 & $1.398 * *$ & 0.093 & 0.001 & 0.00001 \\
\hline & $(0.310)$ & $(0.312)$ & $(0.688)$ & $(0.095)$ & $(0.002)$ & $(0.00001)$ \\
\hline \multirow[t]{2}{*}{ Sol. Rad. (W/m2) } & 0.002 & 0.002 & $0.028 * *$ & 0.001 & -0.00000 & -0.00000 \\
\hline & $(0.002)$ & $(0.002)$ & $(0.014)$ & $(0.0004)$ & $(0.00001)$ & $(0.00000)$ \\
\hline \multirow[t]{2}{*}{ Av. Temp $\left(\mathrm{C}^{\circ}\right)$} & $0.101 * *$ & $0.231 * * *$ & $0.433 * * *$ & $0.057 * * *$ & $0.001 * * *$ & $0.00001 * * *$ \\
\hline & $(0.043)$ & $(0.050)$ & $(0.162)$ & $(0.014)$ & $(0.0004)$ & $(0.00000)$ \\
\hline Wind speed $(\mathrm{m} / \mathrm{s})$ & 0.074 & $0.411 * * *$ & -0.803 & 0.018 & $0.003 * * *$ & -0.00000 \\
\hline$(40.233)$ & $(46.674)$ & $(92.264)$ & $(12.114)$ & $(0.310)$ & $(0.001)$ & \\
\hline Observations & 112 & 112 & 112 & 112 & 112 & 112 \\
\hline Log Likelihood & -87.651 & -99.228 & -34.833 & & & \\
\hline Akaike Inf. Crit. & 191.302 & 214.456 & 85.666 & & & \\
\hline Residual Std. Error $(\mathrm{df}=104)$ & & & & 0.457 & 0.012 & 0.0001 \\
\hline
\end{tabular}




\section{DISCUSSION}

The results of the present paper suggested that floating rafts, covered with two different types of substrate (sandy and vegetal) and placed in an internal wetland area of the Venice lagoon (Valle Averto), were successful in attracting Sterna hirundo breeding pairs for two consecutive years. Our results showed an increasing trend in both the number of individuals and the reproductive success from 2014 to 2015. This observation was supported by the good weather conditions and specifically related to the increase in average temperatures and the decrease in rainfall occurred in 2015. This result was consistent with what had been reported by Becker and colleagues (1985), that a temporary reduction of the breeding success of a Common tern colony in West Germany was due to rainfall increase before egg laying. According to this author, an increase in rainfall in the middle of the breeding season may heavily impact the breeding success of the pairs, in reducing the foraging activity of males; this situation may have occurred in 2014 in Valle Averto, according to the present paper.

The present study also indicated greater distances from the shores as one of the most important habitat factors, that can favour the occurrence and the reproductive success of Common terns. In 2015 distances of the floating rafts were greater than 2014 , leading to the increased trend recorded in the second year of study. The importance of distance from the mainland for the habitat selection of breeding populations was confirmed by other authors for colonies nesting in estuarine habitats (Fasola \& Canova, 1991; Goutner, 1997). Goutner (1997) clearly stated that isolation of islands was the most important factor in favouring bird colonies and the use of isolated artificial and restored habitats is therefore a conservation priority, that is strongly supported by the present study. Again, a large scale study on the abundance and distribution of colonies in the Azores revealed that wind components, monthly variability (seasonal patterns), distance to shore and to seamounts were the most important variables in explaining the observed spatial variability of terns' distribution (Amorim et al., 2009).

Our analysis indicated a higher number of individuals and nesting success in the rafts covered with a windrow of dead plants. This result was consistent with what is reported in literature that indicates a prevalence of Common terns' nests on windrows, in the Venice lagoon (Scarton, 2010). Nesting on this material has in fact some advantages since it provides good camouflage for terns' eggs and it shows a higher survival rate from flooding, since nests are more than $20 \mathrm{~cm}$ above the saltmarsh surface (Burger \& Lesser, 1978; Scarton, 2010).

From the comparison between the GLM and the robust regression models we can state that our results are reliable in assessing the effects of the investigated explanatory variables on the number of Common terns that use the rafts (Table 2). On the contrary, the goodness of GLM models that study the effect of the selected variables on the abundance of breeding pairs and chicks fledged (Table 3 ) should be taken with care, given the rather low coincidence of the models' estimates, in particular for the chicks fledged. However, data related to nesting events were few in the dataset and better results could be obtained with a larger number of observations. Therefore, these analysis are yet to be investigated.

The present paper highlights that the use of artificial habitats, such as isolated floating rafts, in marginal and internal areas of large lagoons, such as the Venice Lagoon, may favour the Common tern nesting, offering to this species supplementary habitats besides the ones already available in the open lagoon (e.g. islets, saltmarshes, natural and artificial, and dredge islands). This is important in the light of the sea level rise and erosion phenomena, that may lead to a consequential reduction of saltmarshes and natural islands in the Venice Lagoon (Carniello et al., 2009), or even their complete disappearance (Cola et al., 2008), as predicted over the next 50 years (Cavraro et al., 2017). The natural habitat reduction and the increased risk of submersion of this species' suitable nesting sites in the Venice lagoon, could be compensated by adopting restoration measures in internal and controlled areas, less subjected to erosion and sea level rise.

However, the floating rafts used in the present project showed some structural and management limitations, that must be overcome before exporting this restoration measure to similar lagoon contexts. The main limitations concerned the difficulty of moving rafts, for the maintenance work, in shallow waters such as in Valle Averto and the small surface of the rafts, which is a limiting factor for the settlement of more than one pair per raft.

Main indications emerging from the present study are: 1) to assure and maintain the rafts' isolation from the mainland in order to prevent predator access and favour the occurrence and reproductive success of Common terns; 2) to cover the floating rafts with windrow to make them more attractive to terns and to enhance the nests' survival rate; 3 ) to enlarge the available surface of rafts in order to increase the number of breeding pairs recorded, currently limited to one per raft.

Future studies will be aimed at including such indications in order to overcome the limits of the floating rafts and testing these restoration measures on different internal areas of the Venice lagoon, to encourage the establishment of new units of breeding Common terns.

\section{Acknowledgments}

We thank the WWF Italia Onlus, for allowing us to implement this experimental project within the naturalistic oasis of Valle Averto, P. Utmar for advices in planning the project and developing the floating rafts, $\mathrm{M}$. Bernardi and R. Borgo for help in realizing them and G. Corò and M. Cocco for collaboration in data collection. Finally, we are particularly grateful to S. Fano for the precious support in the statistical analyses.

\section{REFERENCES}

Amorim P., Figueiredo M., Machete M., Morato T., Martins A., \& Serrão Santos R., 2009 - Spatial variability of seabird distribution associated with environmental factors: a case study of marine Important Bird Areas in the Azores. ICES Journal of Marine Science, 66: 29-40. 
Andren H., 1994 - Effects of habitat fragmentation on birds and mammals in landscapes with different proportions of suitable habitat: a review. Oikos, 71: 355366.

Becker P. H., 1995 - Effects of coloniality on gull predation on Common Tern (Sterna hirundo) chicks. Colonial Waterbirds, 18: 11-22.

Becker P. H., Finck P. \& Anlauf A., 1985 - Rainfall preceding egg-laying - a factor of breeding success in Common Terns (Sterna hirundo). Oecologia, Berlin, 65: 431-436.

Bender, D. J., Contreras T. A. \& Fahrig L.,1998 - Habitat loss and population decline: a meta-analysis of the patch size effect. Ecology, 79: 517-533.

BirdLife International, 2016 - Sterna hirundo. The IUCN Red List of Threatened Species. Version 2017.1. $<$ http://www.iucnredlist.org/details/22694623/0> (downloaded on $3^{\text {th }}$ April 2017).

Bon M., Scarton F., Stival E., Sattin L., Sgorlon G. (a cura di), 2014 - Nuovo atlante degli uccelli nidificanti e svernanti in provincia di Venezia. Associazione Faunisti Veneti, Museo di Storia Naturale di Venezia.

Brichetti P. \& Fracasso G., 2006 - Ornitologia italiana. Stercorariidae-Caprimulgida. Alberto Perdisa Editore, Bologna.

Burger J., 1981 - Personal watercraft and boats. Coastal conflicts with common terns. Lake and Reservoir Management, 19: 26-34.

Burger J., 1998 - Effects of motorboats and personal watercraft on flight behavior over a colony of Common Terns. The Condor, 100: 528-534.

Burger J. \& Lesser F., 1978 - Selection of colony sites and nest sites by Common Terns Sterna hirundo in Ocean County, New Jersey. Ibis, 120: 433-449.

Burgess N. D. \& Hirons G. J., 1992 - Creation and management of artificial nesting sites for wetland birds. Journal of Environmental Management, 34: 285295.

Carney K. M. \& Sydeman W. J., 1999 - A review of human disturbance effects on nesting colonial waterbirds. Waterbirds, 22: 68-79.

Carniello L., Defina A. \& D’Alpaos L., 2009 - Morphological evolution of the Venice lagoon: evidence from the past and trend for the future. Journal of Geophysical Research, 114: 1-10.

Cavraro F., Zucchetta M., Malavasi S. \& Franzoi P., 2017 - Small creeks in a big lagoon: The importance of marginal habitats for fish populations. Ecological Engineering, 99: 228-237.

Clarke I., Stokes Z. \& Wallace R., 2010 - Habitat Restoration Planning Guide for Natural Resource Managers. Government of South Australia, through Department of Environment and Natural Resources, Adelaide.

Cola S., Sanavia L., Simonini P. \& Schrefler B. A., $2008-$ Coupled thermo-hydro-mechanical analysis of Venice lagoon salt marshes. Water Resources Research, 44: $1-16$.

Croxall J. P., Butchart S. H. M., Lascelles B., Stattersfield A. J., Sullivan B., Symes A. \& Taylor P., $2012-$ Se- abird conservation status, threats and priority actions: a global assessment. Bird Conservation International, 22: 1-34.

Dobson A. P., Bradshaw A. \& Baker A. J. M., 1997 - Hopes for the future: restoration ecology and conservation biology. Science, 277: 515-522.

Dunlop C. L., Blokpoel H. \& Jarvie S., 1991 - Nesting rafts as a management tool for a declining common tern (Sterna hirundo) colony. Colonial Waterbirds, 14: 116-120.

Fahrig L., 1997 - Relative effects of habitat loss and fragmentation on population extinction. Journal of Wildlife Management, 61: 603-610.

Fasola M. \& Canova L., 1991 - Colony site selection by eight species of gulls and terns breeding in the «Valli di Comacchio» (Italy). Italian Journal of Zoology, 58: 261-266.

Gill J. A., 2007 - Approaches to measuring the effects of human disturbance on birds. Ibis, 149: 9-14.

Goudie A. S., 2013 - The human impact on the natural environment: past, present, and future. John Wiley \& Sons Eds, Oxford.

Goutner V., 1997 - Use of the Drana Lagoon (Evros Delta, Greece) by threatened colonially nesting waterbirds and its possible restoration. Biological conservation, 81: 113-120.

Grémillet D. \& Boulinier T., 2009 - Spatial ecology and conservation of seabirds facing global climate change: a review. Marine Ecology Progress Series, 391: 121137.

Hlavac M., 2015 - Stargazer: Well-Formatted Regression and Summary Statistics Tables. R package version 5.2 .

Huxel G. R. \& Hastings A., 1999 - Habitat loss, fragmentation, and restoration. Restoration Ecology, 7: 309-315.

Lampman K. P., Taylor M. E. \& Blokpoel H., 1996 - Caspian terns (Sterna caspia) breed successfully on a nesting raft. Colonial Waterbirds, 19: 135-138.

Magella G. \& Brousseau P., 2001 - Does culling predatory gulls enhance the productivity of breeding common terns? Journal of Applied Ecology, 38: 1-8.

Mantyka-pringle C. S., Martin T. G. \& Rhodes J. R., 2012 - Interactions between climate and habitat loss effects on biodiversity: a systematic review and meta-analysis. Global Change Biology, 18: 12391252.

Miller J. R. \& Hobbs R. J., 2007 - Habitat restoration. Do we know what we're doing? Restoration Ecology, 15: 382-390.

O'Connell T. J. \& Beck R. A., 2003 - Gull predation limits nesting success of terns and skimmers on the Virginia barrier islands. Journal of Field Ornithology, 74: 66-73.

Peronace V., Cecere J. G., Gustin M. \& Rondinini C., 2012 - Lista Rossa 2011 degli uccelli nidificanti in Italia. Avocetta, 36: 11-58.

$\mathrm{R}$ Core Team, 2016 - R: A language and environment for statistical computing. R Foundation for Statistical Computing, Vienna. Available from <https://www.Rproject.org $>$ 
Rocco A. \& Utmar P., 2011 - Isolotti artificiali: sviluppo di una colonia di Larolimicoli Charadriformes nella Riserva Naturale Regionale della Valle Cavanata, Grado, Friuli Venezia Giulia. In: Atti XVI Convegno Italiano di Ornitologia. Cervia (RA), 22-25 settembre 2011. Tinarelli R., Andreotti A., Baccetti N., Melega L., Roscelli F., Serra L., Zenatello M. (a cura di). Scritti, Studi e Ricerche di Storia Naturale della Repubblica di San Marino: 212-213.

Scarton F., 2008 - Population trend, colony size and distribution of little terns in the lagoon of Venice (Italy) between 1989 and 2003. Waterbirds, 31: 35-41.

Scarton F., 2010 - Long term decline of a Common Tern (Sterna hirundo) population nesting in salt marshes in Venice lagoon, Italy. Wetlands, 30: 1153-1159.

Scarton F. \& Valle R., 2016 - Long-term trends (19892013 ) in the seabird community breeding in the lagoon of Venice (Italy). Rivista Italiana di Ornitologia, 85: 19-28.

Tilman D., May R. M., Lehman C. L. \& Nowak M. A., 1994 - Habitat destruction and the extinction debt. Nature, 371: 65-66.

Valle R. \& Scarton F., 1999 - The presence of conspicuous associates protects nesting Redshank Tringa totanus from aerial predators. Ornis Fennica, 76: 145-148. 